JózEF ŻYCHOWSKI

Uniwersytet Pedagogiczny w Krakowie, Polska - Pedagogical University of Krakow, Poland

WITOLD JUCHA

Uniwersytet Pedagogiczny w Krakowie, Polska - Pedagogical University of Krakow, Poland

\title{
Zmiany ustrojowe i rozwój przedsiębiorczości jako czynniki wpływające na strukturę pokrycia i użytkowania terenu na przykładzie zlewni Bełczy i Mszanki w Beskidzie Niskim
}

\section{Political Changes and Development of Entrepreneurship as Factors Influencing Land Cover and Land Use Structure Based on the Example of Bełcza and Mszanka Catchment Areas in Beskid Niski Mountain Range}

Streszczenie: $\mathrm{W}$ artykule przedstawiono stan zagospodarowania i formy przedsiębiorczej działalności człowieka w dwóch zlewniach położonych w Beskidzie Niskim. Przesłanką do podjęcia badań było często opisywane zjawisko zaniku działalności gospodarczej w obszarach górskich, szczególnie w sektorze rolnictwa. Jednym z celów było sprawdzenie, czy we wskazanych zlewniach również wystąpiły zmiany i jaki był ich kierunek, także w perspektywie historycznej. Podano też czynniki, które mogły mieć wpływ na ukształtowanie się postaw przedsiębiorczych w tamtym rejonie. Przykłady zawarte w artykule mogą być przydatne w nauczaniu podstaw przedsiębiorczości w szkole średniej. Dane historyczne pozyskano za pomocą kwerendy literatury przedmiotu. Informacje o liczbie ludności oraz gospodarstw i przedsiębiorstw lokalnych zebrano w urzędzie gminy Dukla, jej sołectwach oraz za pomocą wywiadów środowiskowych. Zmiany pokrycia terenu określono na podstawie dwóch materiałów źródłowych (z 1978 i 2015 r.) opracowanych w GIS. Pomimo znaczących przemian politycznych, ekonomicznych i społecznych (wymiana ludności, przerwane nagle funkcjonowanie Państwowych Gospodarstw Rolnych - PGR-ów, wyludnianie się wsi) na terenie obu zlewni funkcjonują zarówno gospodarstwa rolne, jak i agroturystyczne, dzięki czemu obecna struktura pokrycia terenu jest podobna do stwierdzonej w latach 70. XX w. Wprowadzenie dopłat unijnych do rolnictwa zachęciło przedsiębiorców do przejmowania państwowych gruntów rolnych i ich zagospodarowania. Przykład ten warto omówić na lekcji przedsiębiorczości.

Abstract: The article presents the state of development and forms of entrepreneurship in two catchments located in the Beskid Niski mountain range. The often described process of the disappearance of economic activity in mountain areas, especially agriculture, was the reason for undertaking the research. The purpose was to check these changes and their directions in the catchment areas, also in a historical 
perspective. Factors that could have influenced the formation of entrepreneurial attitudes were given. The examples in the article can be useful in delivering topics during entrepreneurship classes in high school. Historical data was obtained through literature query. Information about the population, farms and local enterprises was collected at the Dukla commune office and village councils and through interviews. Changes in land cover were determined in GIS on the basis of two source materials (from 1978 and 2015). Despite significant political, economic and social changes (population exchange, sudden dissolution of State Agricultural Farms, depopulation of villages), both agricultural and agro-tourist farms operate in the catchments. The current land cover structure is similar to the 1970s. The EU subsidies for agriculture has encouraged entrepreneurs to take over state-owned agricultural land and their development. This case is worth discussing during entrepreneurship classes.

Słowa kluczowe: czynniki polityczno-społeczne; obszary górskie; studium przypadku; zmiany użytkowania i pokrycia terenu

Keywords: case study; changes in land use/land cover; mountain areas; political and social factors

Otrzymano: 14 października 2019

Received: 14 October 2019

Zaakceptowano: 15 marca 2020

Accepted: 15 March 2020

\section{Sugerowana cytacja/Suggested citation:}

Żychowski, J., Jucha, W. (2020). Zmiany ustrojowe i rozwój przedsiębiorczości jako czynniki wpływające na strukturę pokrycia i użytkowania terenu na przykładzie zlewni Bełczy i Mszanki w Beskidzie Niskim. Przedsiębiorczość - Edukacja [Entrepreneurship - Education], 16(1), 275-289. doi: 10.24917/20833296.161.22

\section{Wstęp}

Działalność i przedsiębiorczość ludzi wpływają na wygląd i charakter danego obszaru. Oddziaływanie to zmienia się w czasie zarówno ze względu na zewnętrzne uwarunkowania polityczne, ekonomiczne i społeczne, jak i ze względu na mentalność oraz inicjatywy mieszkańców. Pośrednie skutki zmian aktywności gospodarczej można obserwować w strukturze pokrycia i użytkowania terenu, takie jak zwiększenie lub zmniejszenie proporcji powierzchni zajętych przez obszary użytkowane rolniczo lub przemysłowo w stosunku do tych, na których dominuje sukcesja prowadząca do wzrostu zalesienia w pokryciu. Od drugiej połowy XX w. obserwowano stopniowy zanik obszarów użytkowanych rolniczo w polskich górach, zwłaszcza w Beskidach (Bucała, 2014; Bucała-Hrabia, 2018; Kroczak i in., 2018). W konsekwencji postępowało stopniowe zalesianie i zmieniały się proporcje terenów naturalnych i antropogenicznych (Bucała-Hrabia, 2018; Dorocki, Kroczak, Bryndal, 2019; Jucha, 2017; Kaim, 2009; Kozak, 2005; Kroczak i in., 2018). Proces ten jest obserwowany także w wielu innych górskich regionach Europy (Meyfroidt, Lambin, 2011).

Istotną przyczyną tego zjawiska jest niższa produktywność rolniczych terenów górskich związana z niską żyznością i urodzajnością gleby oraz z niesprzyjającymi warunkami klimatycznymi (Bucała-Hrabia, 2018). Ponadto na obszarach tych wyższe są koszty upraw, co wynika m.in. z: rozdrobnienia gruntów rolnych czy wyższych kosztów stosowania maszyn na stokach. Istotnym problemem społecznym jest zanik postaw przedsiębiorczych w warunkach wcześniejszego ustroju. Z kolei zachowanie przynajmniej części 
z górskich obszarów rolniczych uważa się za korzystne dla środowiska i bioróżnorodności. W związku z tym od 2004 r. Unia Europejska (UE) przez system dopłat wspiera niektóre praktyki rolnicze, takie jak wykaszanie lub tzw. wypas kulturowy, co jest dodatkowym czynnikiem modyfikującym użytkowanie gruntów i lokalną przedsiębiorczość.

W niniejszym artykule przedstawiono studium przypadku wykonane dla kilku miejscowości znajdujących się w południowo-wschodniej Polsce, w których prowadzona jest działalność rolnicza na terenie dwóch górskich zlewni. Podjęto w nim analizę rozwoju tych miejscowości z perspektywy historycznej, jak również zbadano aktualny stan zagospodarowania i przedsiębiorczości. Szczególną uwagę zwrócono na wpływ zmian ustrojowych i rozwoju przedsiębiorczości na zmiany w użytkowaniu terenu, w okresie dwóch ostatnich etapów: w latach powojennych oraz po zmianach ustrojowo-gospodarczych w Polsce.

Przedstawiony przykład stanowi materiał możliwy do wykorzystania przez nauczycieli przedsiębiorczości zgodnie z nową podstawą programową dla szkoły średniej, która wejdzie w życie w roku szkolnym 2020/2021. W programie tym zwraca się uwagę na dostrzeganie różnych aspektów analizowanych zjawisk społeczno-ekonomicznych i ich oceny w wyniku wieloaspektowej, rzetelnej dyskusji (Rachwał, 2018). Realizacja założonych treści wymaga spojrzenia na problem z punktu widzenia wielu dyscyplin (Świętek, 2019). Istotą opisanego w artykule przykładu jest fakt, że zjawisko zaniku powierzchni użytkowanych rolniczo wystąpiło na zbadanym terenie w bardzo ograniczonym stopniu. Wskazane w tekście zmiany uwarunkowań oraz związana z nimi działalność gospodarcza stanowią uzupełnienie wiedzy innych wyników badań i mogą być przedmiotem do dyskusji z uczniami na zajęciach z podstaw przedsiębiorczości.

\section{Cel, przedmiot i obszar badań}

W artykule postawiono następujące cele:

- Wskazanie poziomu istotności i kierunków zmian w działalności gospodarczej na wybranym terenie badań i związanych z nimi form użytkowania i pokrycia terenu.

- Przedstawienie funkcjonowania wybranych wsi w Beskidzie Niskim w ostatnich kilkudziesięciu latach, w tym związanych z nim form gospodarczych.

- Scharakteryzowanie czynników, które wpłynęły na zmiany w zagospodarowaniu wsi oraz w użytkowaniu i pokryciu terenu.

Na potrzeby artykułu zbadano współczesny stan liczby ludności i prowadzonej przez nią działalności gospodarczej oraz zmiany, które zaszły w tym zakresie w ciągu ostatnich kilkudziesięciu lat. Zwrócono także uwagę na rys historyczny w szerszej perspektywie, uwzględniając czynniki polityczne, ekonomiczne i społeczne w funkcjonowaniu wsi: przed II wojną światową, w czasie II wojny, w okresie po powojennych wysiedleniach, gdy działalność prowadziły Państwowe Gospodarstwa Rolne (PGR-y), po ich likwidacji PGR-ów oraz po wprowadzeniu dopłat unijnych. W dalszej części tekstu uwzględniono zmiany w użytkowaniu terenu, które były ich konsekwencją.

Badaniami objęto wsie położone w dwóch zlewniach potoków górskich płynących na południowym wschodzie Polski, w Beskidzie Niskim, w województwie podkarpackim (rycina 1). Wsie te leżą na terenie zlewni potoku Mszanka w gminie Dukla oraz w zlewni potoku Bełcza w gminie Jaśliska. Wydzielenia te tworzyły w przeszłości samodzielne systemy - mieszkańcy wsi położonych w wymienionych zlewniach prowadzili działalność 
Rycina 1. Lokalizacja terenu badań

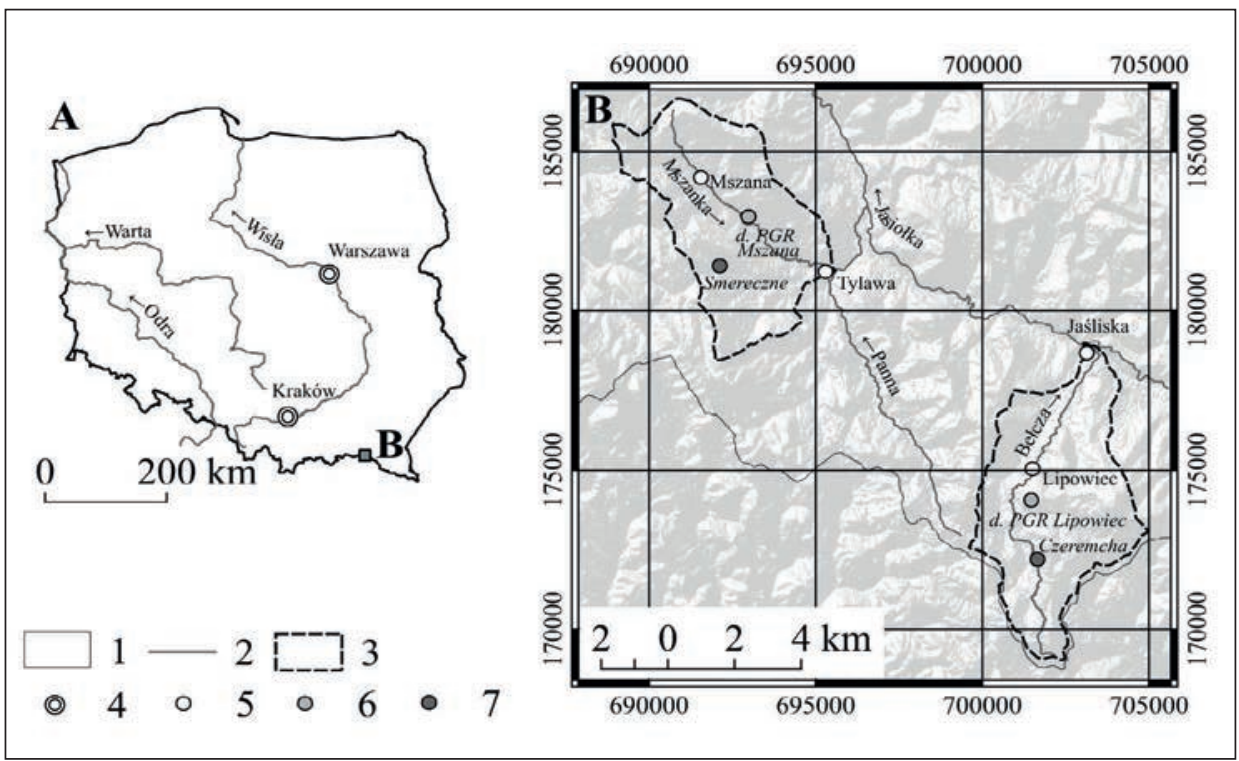

1 - granice państwa, 2 - rzeki i potoki, 3 - granice zlewni, 4 - miasta (A), 5 - miejscowości obszaru badań, 6 - dawne PGR-y, 7 - miejscowości obecnie nieistniejące

Źródło: opracowanie własne

tylko w ich obrębie. Ponadto dysponowano ilościowymi i jakościowymi właściwościami środowiska geograficznego tych zlewni (Żychowski, 2000).

Obie zlewnie charakteryzują się podobną wielkością, ok. $28 \mathrm{~km}^{2}$, oraz układem zabudowy wzdłuż potoków. W pobliżu ujścia potoków znajdują się zabudowania dużych wsi leżących w dolinach recypientów - Jaśliska i Tylawa. Tylko niewielkie fragmenty tych wsi są położone w dolnych częściach zlewni. W środkowej części każdego wydzielenia znajduje się mniejsza wieś: Mszana w zlewni Mszanki i Lipowiec w zlewni Bełczy, ponadto w każdej z miejscowości znajdował się PGR. W obu zlewniach istniały także obecnie nieistniejące wsie łemkowskie: Smereczne w dolinie Smereczanki (Wadernika) dopływającej do Mszanki oraz Czeremcha w górnej części zlewni Bełczy.

\section{Materiały i metody}

W celu przygotowania tła historycznego i określenia aktualnego stanu zagospodarowania badanych obszarów przeprowadzono kwerendę literatury. Część informacji uzupełniono na postawie wywiadów środowiskowych $\mathrm{z}$ sołtysami wsi i wybranymi losowo mieszkańcami, które to wywiady przeprowadzono podczas badań terenowych prowadzonych w latach 80. XX w. oraz w 2019 r. W trakcie prac powstała także dokumentacja fotograficzna obecnego stanu użytkowania terenu. Informacje statystyczne na temat liczby mieszkańców oraz podmiotów gospodarczych uzyskano w urzędach gmin Dukla i Jaśliska.

Badanie zmian pokrycia terenu przeprowadzono z użyciem oprogramowania GIS. Archiwalnym materiałem źródłowym był zestaw zdjęć lotniczych wykonanych w 1978 r., które poddano rektyfikacji do układu współrzędnych 1992. Zdjęcia pochodziły ze Zbiorów 
Kartograficznych IG UP. Współczesnym źródłem informacji była Ortofotomapa Polski z 2015 r. Oba źródła poddano fotointerpretacji w celu otrzymania map pokrycia terenu dla dwóch okresów. W czasie wektoryzacji użyto podziału na trzy klasy: lasy, tereny nieleśne (dodatkowy subpodział na pola uprawne oraz łąki, pastwiska i tereny zielone), tereny zabudowane (budynki + obejścia). Następnie zbadano istotność statystyczną występujących różnic w udziale poszczególnych klas za pomocą testu $\chi^{2}$ oraz podobieństwo przestrzenne pokrycia terenu dla obu okresów z użyciem współczynnika podobieństwa Kappa. W teście wykorzystano informacje o łącznych powierzchniach poszczególnych klas, a następnie sprawdzono, które z nich w największym stopniu mogły wpłynąć na istotność statystyczną obserwowanych zmian. Współczynnik podobieństwa Kappa składa się z trzech miar: podobieństwa proporcji klas Kappa histo, podobieństwa położenia klas na mapie Kappa location oraz będącego ich pochodną współczynnika podobieństwa ogólnego Kappa overall. Należy on do podstawowych wskaźników zmian w pokryciu terenu. Jego wartość można zinterpretować jako procent areału, który w zbadanym okresie nie uległ zmianie. Przyjmuje on wartości między 0 a 1, gdzie 0 oznacza całkowitą zmianę, czyli brak podobieństwa, a 1 brak jakichkolwiek zmian, czyli całkowitą zgodność. Porównanie z danymi z wcześniejszego okresu jest bardzo utrudnione lub niemożliwe z powodu ich dużej niekompletności, dlatego skorzystano także z innych źródeł, w tym z map i wywiadów środowiskowych.

\section{Zarys historycznego i obecnego stanu zagospodarowania - zlewnia Bełczy}

Pierwsze wzmianki o znajdującej się na terenie zlewni Bełczy wsi Lipowiec (rycina 1B) pochodzą z 1527 r. Była to wówczas wieś wołoska leżąca w pobliżu szlaku wiodącego na południe Europy (Fastnacht, 1962; Jawor, 2004; Figlus, 2016). Pola uprawne wsi znajdowały się w pasie między zabudową a granicą lasu, co nawiązywało do tzw. łanów leśnych (Dobrowolski, 1930). Jej zabudowa rozciągała się w dnie doliny Bełczy, w środkowym odcinku tego potoku. Do końca XIX w. wieś Lipowiec była kilkukrotnie niszczona i odbudowywana, co ograniczało jej rozwój, np. w 1657 r. zniszczenia wynikały z przemarszów wojsk Rakoczego, w 1849 r. straty powstały w wyniku przemarszu wojsk carskich do Austrii w celu stłumienia powstania węgierskiego. Mieszkańcy wsi przynależeli do cerkwi greckokatolickiej, a w okresie międzywojennym przeszli na prawosławie w wyniku tzw. schizmy tylawskiej. W 1880 r. Lipowiec liczył 560 mieszkańców.

Teren zlewni Bełczy był miejscem walk w czasie I wojny światowej, o czym świadczą częściowo zachowane ślady umocnień na górze Kamień. W czasie działań wojennych zniszczona została 1/3 zabudowy Lipowca. Dalsze zniszczenia spowodowane zostały walkami podczas II wojny światowej, toczącymi się we wrześniu $1944 \mathrm{r}$. Zostało wówczas zniszczonych lub uszkodzonych 60 budynków wsi, zaś Radziecka Komisja Przesiedleńcza zadecydowała o przeniesieniu mieszkańców na teren ZSRR. Zabudowania pozostałe po wysiedleńcach, z wyjątkiem 3 budynków, zostały spalone przez sotnię Ukraińskiej Powstańczej Armii (UPA) „Hrynia”.

Po wojnie wieś Lipowiec zamieszkiwało 18 osób. Oprócz tego założono w niej PGR (fotografia 1B) będący filią PGR Puławy. W budynkach mieszkalnych przedsiębiorstwa zameldowanych było 31 pracowników, a pozostali dojeżdżali do pracy spoza terenu wsi. Na obszarze wsi funkcjonowała także placówka Wojsk Ochrony Pogranicza (WOP), licząca 29 osób. Po przemianach ustrojowych w roku 1990, likwidacji PGR-u i wspomnianej placówki, na terenie Lipowca pozostało zameldowanych jedynie 6 osób. 
Fotografie 1A-1D. Współczesne obiekty na terenie zlewni Bełczy
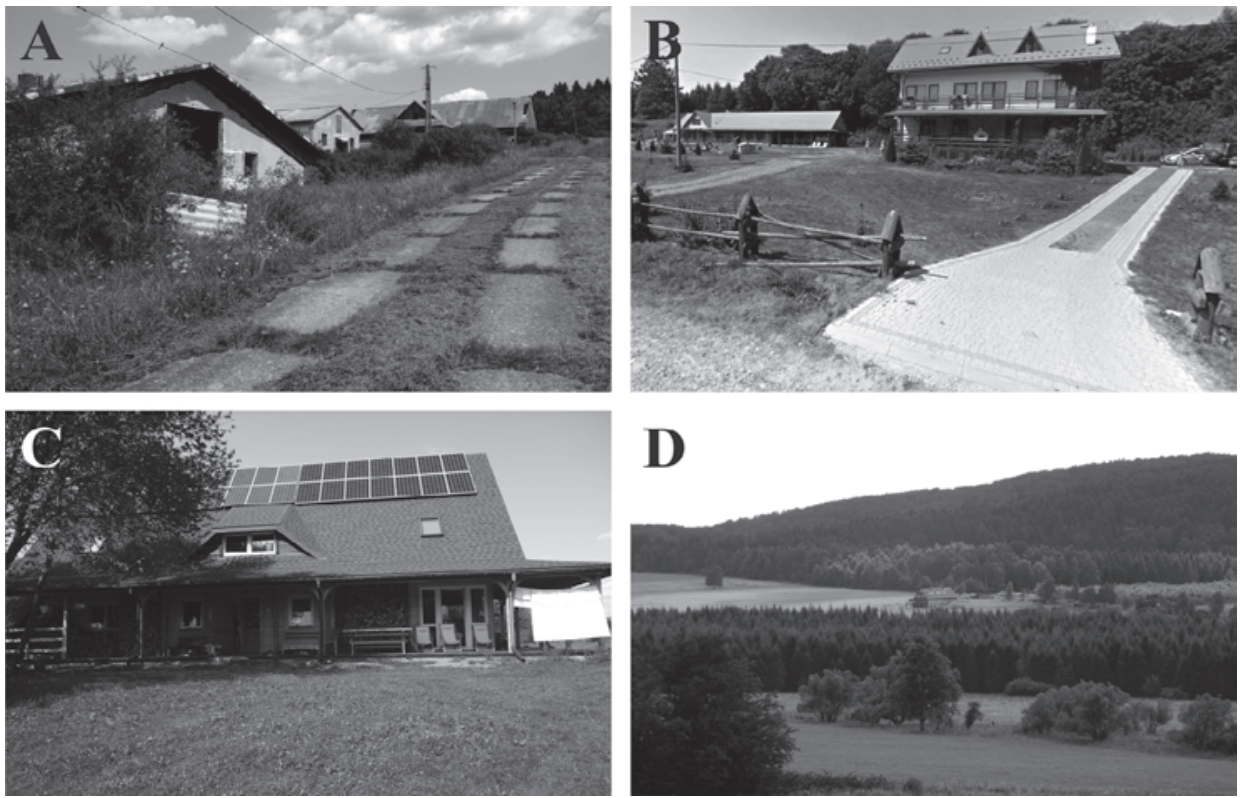

A - zabudowania d. PGR „Lipowiec”, w trakcie przebudowy; B - gospodarstwo „Ostoja w Lipowcu”, C - chata ekoturystyczna „Gutkowa Koliba”, D - nowy budynek na terenie dawnej wsi Czeremcha

Źródło: fot. J. Żychowski, 2019

Obecnie zabudowania po dawnym PGR-ze Lipowiec zostały wykupione wraz z przyległym gruntem o powierzchni 30 ha przez prywatnego inwestora $\mathrm{z}$ województwa lubelskiego, który zamierza przystosować je pod miejsca noclegowe (fotografia 1A). Trudności z przystosowaniem dotyczą zwłaszcza dużych powierzchniowo dachów pokrytych eternitem, który trzeba wymienić. Z kolei na terenie wsi Lipowiec powstały dwa podmioty agroturystyczne. Pierwszym z nich jest Gospodarstwo Agroturystyczne „Ostoja w Lipowcu" (http://www.lipowiec.pl/; fotografia 1B). Dysponuje ono 53 miejscami noclegowymi wysokiego standardu. W jego ofercie znajdują się produkty spożywcze własnego wyrobu. Prowadzi ono także stadninę koni. Drugim jest rodzinna chata ekoturystyczna „Gutkowa Koliba” (http://www.gutkowa-koliba.pl/; fotografia 1C), dysponująca łącznie 10 miejscami noclegowymi. Budynek mieszkalny ma instalację fotowoltaiczną i własną biologiczną oczyszczalnię ścieków.

Wzmianki o dawnej wsi Czeremcha leżącej w górnej części zlewni Bełczy również zaczynają się od roku 1527. Mieszkańcami tej wsi byli głównie greckokatoliccy Łemkowie. W 1761 r. we wsi powstała cerkiew. W 1880 r. wieś zamieszkiwało 500 osób. Prawie połowa zabudowań wsi została zniszczona podczas I wojny światowej. Czeremcha została ostatecznie zlikwidowana w czasie II wojny światowej, a jej mieszkańców wywieziono do ZSRR (Barwiński, 2009). Na terenie dawnej wsi stoi obecnie jeden dom wybudowany w czasach współczesnych, niepodłączony do sieci energetycznej. Jest on zamieszkiwany tylko sezonowo (fotografia 1D).

Grunty użytkowane rolniczo, przynależące do dawnych mieszkańców obu wsi, podlegały bezpośrednio po wojnie naturalnej sukcesji roślinności, która następnie została 
zahamowana przez działalność PGR-u. Prowadził on hodowlę krów na użytkach zielonych w postaci łąk i pastwisk, które zajmowały tereny o większym nachyleniu. Po $1990 \mathrm{r}$. czasowo zaprzestano użytkowania większości terenów, lecz powrócono do niego po 2004 r. Już w początkowym okresie kilka osób przejęło teren PGR-u w ajencję. Obecnie zdecydowanie większe zainteresowanie utrzymywaniem na tych terenach łąk kośnych spowodowały dotacje z programów unijnych. Areał różnej wielkości (od 20 ha do 170 ha) został wykupiony przez prywatnych inwestorów, którzy regularnie wykaszają należące do siebie obszary zgodnie z programem unijnym. W dalszym ciągu prowadzi się sprzedaż gruntów w tej zlewni.

\section{Zarys historycznego i obecnego stanu zagospodarowania - zlewnia Mszanki}

Informacje o znajdującej się na obszarze zlewni Mszanki miejscowości Mszana pojawiają się już w XIV w. w akcie prawnym wydanym przez króla Kazimierza III Wielkiego. Pierwotnie prawo osiedlenia się i lokacji na prawie niemieckim przyznano tu osadnikom polskim (Czajkowski, 1999). W XVI w. do miejscowości dotarli Wołosi, za sprawą których Mszana uległa rutenizacji. Mieszkańcy stopniowo przejmowali kulturę rusińską i stawali się grekokatolikami (Figlus, 2016). W roku 1880 wieś liczyła 920 mieszkańców. Istniało w niej także kilka przedsiębiorstw, m.in. olejarnia oraz folusz (zakład obróbki sukna). W przeciwieństwie do wsi w zlewni Bełczy miejscowość nie ucierpiała w wyniku I wojny światowej. W dwudziestoleciu międzywojennym wieś również uczestniczyła w schizmie tylawskiej, w całości przechodząc z religii greckokatolickiej na prawosławie w 1926 r. (Moklak, 2013).

Mszana poważnie ucierpiała w czasie II wojny światowej, zwłaszcza podczas tzw. operacji dukielsko-preszowskiej (Andrusikiewicz, 1968). Podobnie jak w miejscowościach w zlewni Bełczy, większość jej mieszkańców została wysiedlona do ZSRR w roku 1944. Pozostałych mieszkańców natomiast deportowano w ramach akcji „Wisła” w 1947 r. Mimo to wieś nie uległa likwidacji, ponieważ przesiedlono do niej Polaków ze zniszczonej Huty Polańskiej, leżącej w odległości 10 km. Liczba mieszkańców zmniejszyła się jednak czterokrotnie, z 1235 w roku 1936 do ok. 300 w latach 60. XX w.

Tereny rolnicze w zlewni Mszanki przez kilka lat po wojnie były jedynie wykaszane przez wojsko. Przez krótki czas był na nich prowadzony wypas owiec sprowadzonych z Podhala. Następnie w latach 70. XX w. założono w Mszanie PGR - filię zakładu Igloopol z Dębicy, która istniała w latach 1978-1991. Był on nastawiony na produkcję pasz oraz hodowlę bydła, dlatego zdecydowana większość, ok. 94\% terenów rolniczych, przypadała na pastwiska i łąki kośne. PGR dysponował tartakiem oraz suszarnią pasz. Dla pracowników zbudowano także blok mieszkalny (fotografia 2A).

Obecnie miejscowość powoli wyludnia się z uwagi na to, że wielu ludzi wyemigrowało z niej za pracą. Pozostali w niej głównie emeryci. Ujemny bilans liczby mieszkańców obrazują dane z Urzędu Gminy Dukla. Pomiędzy 1994 a 2018 r. nastąpił spadek osób zameldowanych z 305 do 264 . Liczby te mają charakter orientacyjny, ponieważ nie wiadomo, ile dokładnie osób wyjechało za granicę i nadal figuruje w statystykach jako osoby zameldowane na terenie Mszany.

Również w Mszanie po likwidacji PGR-u na dotychczas użytkowanych łąkach nastąpiła sukcesja roślinności naturalnej (zakrzewienie). Proces ten jednak został zahamowany, a nawet wykarczowano bardziej dostępne miejsca z powodu wprowadzenia dopłat po 
Fotografie 2A-2D. Współczesne obiekty i formy użytkowania na terenie zlewni Mszanki
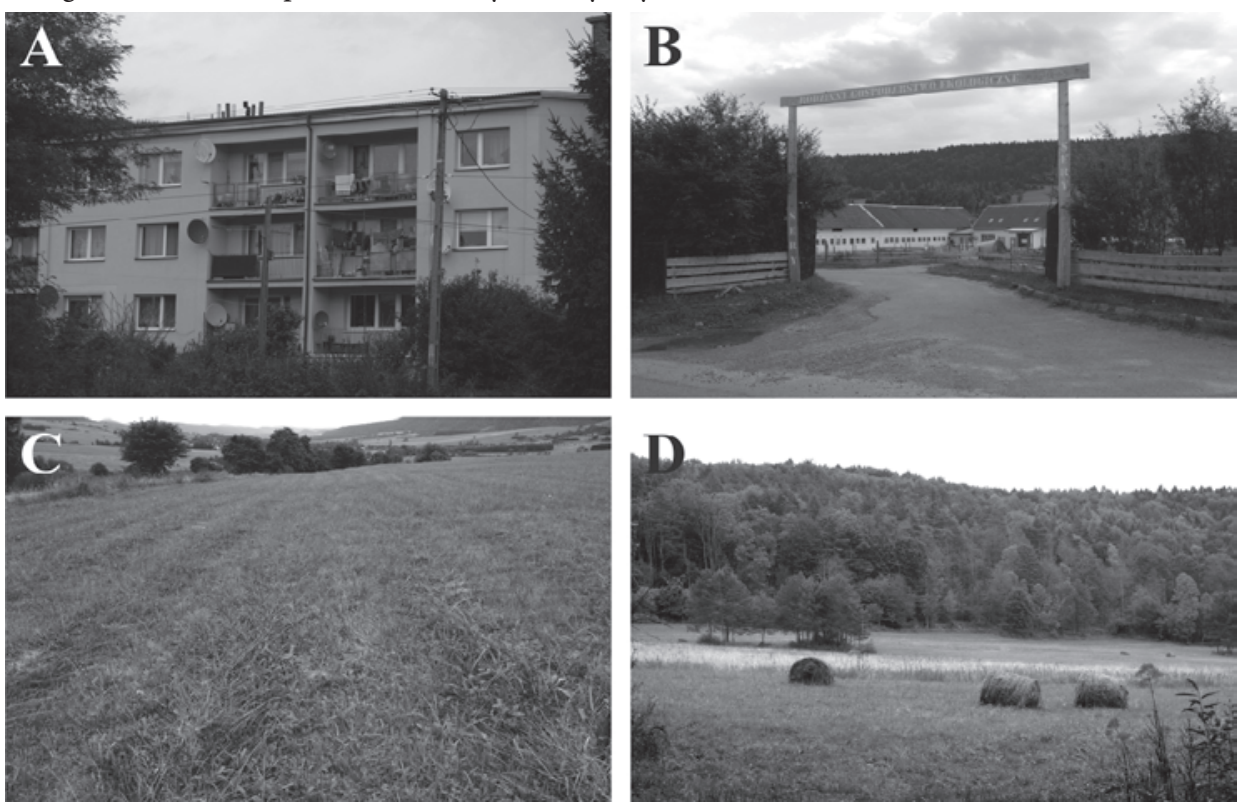

A - budynek mieszkalny d. PGR Mszana; B - dawne zabudowania PGR w Mszanie - obecnie Rodzinne Gospodarstwo Ekologiczne „Figa”, C - skoszona łąka w ramach dopłat - nowo rosnąca trawa przerasta wcześniej skoszoną i niezebraną, D - współczesny widok koszonych łąk w dawnej wsi Smereczne

Źródło: fot. J. Żychowski, 2019

wejściu do Unii Europejskiej. Część pól po PGR-ze jest koszona na potrzeby działających przedsiębiorstw produkcyjnych, a część - wyłącznie ze względu na dopłaty. Dowodem na to jest brak dalszego wykorzystania koszonej trawy (fotografia 2C).

Na obszarze dawnego PGR-u funkcjonuje obecnie prywatne przedsiębiorstwo rolnicze, które prowadzi hodowlę kóz i wytwarza tradycyjne produkty mleczarskie i serowarskie na bazie mleka koziego (fotografia $2 \mathrm{~B}$ ). W gospodarstwie hodowanych jest obecnie kilkaset kóz, a sam zakład ma od roku 2002 status gospodarstwa ekologicznego. Oprócz niego na terenie byłego PGR-u funkcjonuje jeszcze gospodarstwo liczące sześć krów mlecznych.

W zlewni Mszanki znajdowała się także wieś Smereczne, licząca w różnych okresach od 150 do 300 mieszkańców. Była to założona w XVI w. wieś wołoska, greckokatolicka. Zlokalizowano ją w dnie doliny potoku Wadernik. Jej zabudowa rozciągała się wzdłuż drogi łączącej Tylawę i Olchowiec (Hudyk, 2016). Mieszkańcy utrzymywali się z rolnictwa. W większości gospodarowali na powierzchni od 2 ha do 5 ha. We wsi wybudowano nawet dwa szyby wiertnicze w celu wydobywania ropy naftowej. Było to w roku 1875 i 1881.

Miejscowość została zniszczona w czasie I wojny światowej, a następnie w ciągu 3 lat odbudowana przez powracających mieszkańców. Większa tragedia spotkała jej mieszkańców we wrześniu 1944 r., kiedy to w ciągu 12 dni walk o Smereczne zniszczono znacznie zabudowę. Po tym wydarzeniu wsi nie odbudowywano. Po wojnie większość mieszkańców wywieziono do ZSRR, a ostatnie 10 rodzin zostało z niej wysiedlonych w ramach akcji „Wisła” w roku 1947. Grunty wcześniej użytkowane były po wojnie wykorzystywane przez PGR w Mszanie. Obecnie zostały wykupione przez osobę prywatną, która prowadzi 
na nich wykaszanie łąk zgodnie z wymogami unijnych dopłat (fot. 2D). Ponadto właściciel udrożnił rowy w celu drenażu zbyt wilgotnych łąk, a lokalnie nawet karczuje zadrzewienia i zakrzewienia.

\section{Zmiany pokrycia terenu}

Zlewnie Bełczy i Mszanki w ciągu wielowiekowej działalności człowieka stały się obszarami o typowym dla Beskidów układzie zagospodarowania: w dnie doliny znalazła się zabudowa wsi, powyżej - łąki, pastwiska i pola uprawne, natomiast górne, strome części stoków górskich opanował las. Zebrany materiał fotogrametryczny prezentuje stan pokrycia terenu w dwóch momentach, które dzieli niecałych 40 lat (rycina 2). Obserwowane zmiany dotyczyły ostatnich wydarzeń w dziejach opisywanych miejscowości. Czeremcha i Smereczne już nie istniały w 1978 r., natomiast w Lipowcu i Mszanie zaszły znaczne zmiany demograficzne, które dotyczyły zmniejszenia liczby ludności oraz składu narodowościowego i religijnego. Powstały także PGR-y, które zlikwidowano po przemianach ustrojowych. W Lipowcu pozostało kilka osób, natomiast Mszanka stopniowo się wyludnia. Na terenie obu zlewni pojawiły się nowe czynniki rozwoju w postaci prywatnej przedsiębiorczości i środków finansowych z programów Unii Europejskiej.

Tereny rolnicze w zlewni Bełczy występują w dwóch obszarach: w górnej części, na obszarze dawnej wsi Czeremcha, oraz w dolnej części, uprawiane przez mieszkańców wsi Jaśliska (rycina 2B). Właściciele działek położonych w górnych częściach prawego zbocza Bełczy stopniowo zaprzestają uprawiania ziemi, przez co granica rolno-leśna zaczyna przesuwać się w dół stoku. Natomiast wokół wsi Lipowiec w środkowej części zlewni użytki zielone zajmują znacznie węższy pas w związku z przełomowym odcinkiem doliny potoku. W przełomie las sięga do samego dna doliny. W obu badanych okresach wśród terenów rolniczych dominowały łąki i pastwiska, a jedynie sporadycznie występowały grunty orne. Główną zmianą na terenie zlewni był wzrost powierzchni zajmowanych przez lasy o 6\%, z 70\% do 76\%. Tereny zabudowane zarówno w 1978, jak i w 2015 r., zajmowały ok. 1\% obszaru. Zaobserwowane zmiany udziałów poszczególnych typów pokrycia w zlewni Bełczy pomiędzy rokiem 1978 a 2015 były niewielkie i nieistotne statystycznie $\left(\chi^{2}=0,786 ; \mathrm{df}=3 ; \mathrm{p}<0,05\right)$.

Dolina Mszanki jest użytkowana rolniczo wzdłuż całej długości potoku, jak również w środkowej i górnej części dopływu Smereczanki (rycina 2M). W obu okresach zlewnia tego potoku charakteryzowała się niższą o ok. 13\% lesistością w porównaniu ze zlewnią Bełczy. Również tutaj w areale użytków rolnych grunty orne zajmowały symboliczną powierzchnię, podobnie jak i tereny zabudowane, które zajmowały $1 \%$ obszaru w obu okresach. Główną zmianą był wzrost powierzchni leśnych o 6\%, z 57\% do 63\%. Zaobserwowane zmiany w zlewni Mszanki pomiędzy rokiem 1978 a 2015 były niewielkie i nieistotne statystycznie $\left(\chi^{2}=0,997 ; \mathrm{df}=3 ; \mathrm{p}<0,05\right)$.

Mapy pokrycia terenu zarówno dla zlewni Bełczy, jak i dla zlewni Mszanki wykazują bardzo duży stopień zgodności wyrażony współczynnikiem Kappa i jego składowymi (tabela 1). Zmiany i przejścia klas dotyczyły w obu przypadkach około 5-6\% powierzchni. Związane to było ze stopniowym zarastaniem polan śródleśnych oraz niektórych terenów rolniczych, położonych w mniej korzystnych obszarach. 
Rycina 2. Mapy użytkowania terenu w zlewniach Bełczy (B) i Mszanki (M) w latach 1978 i 2015

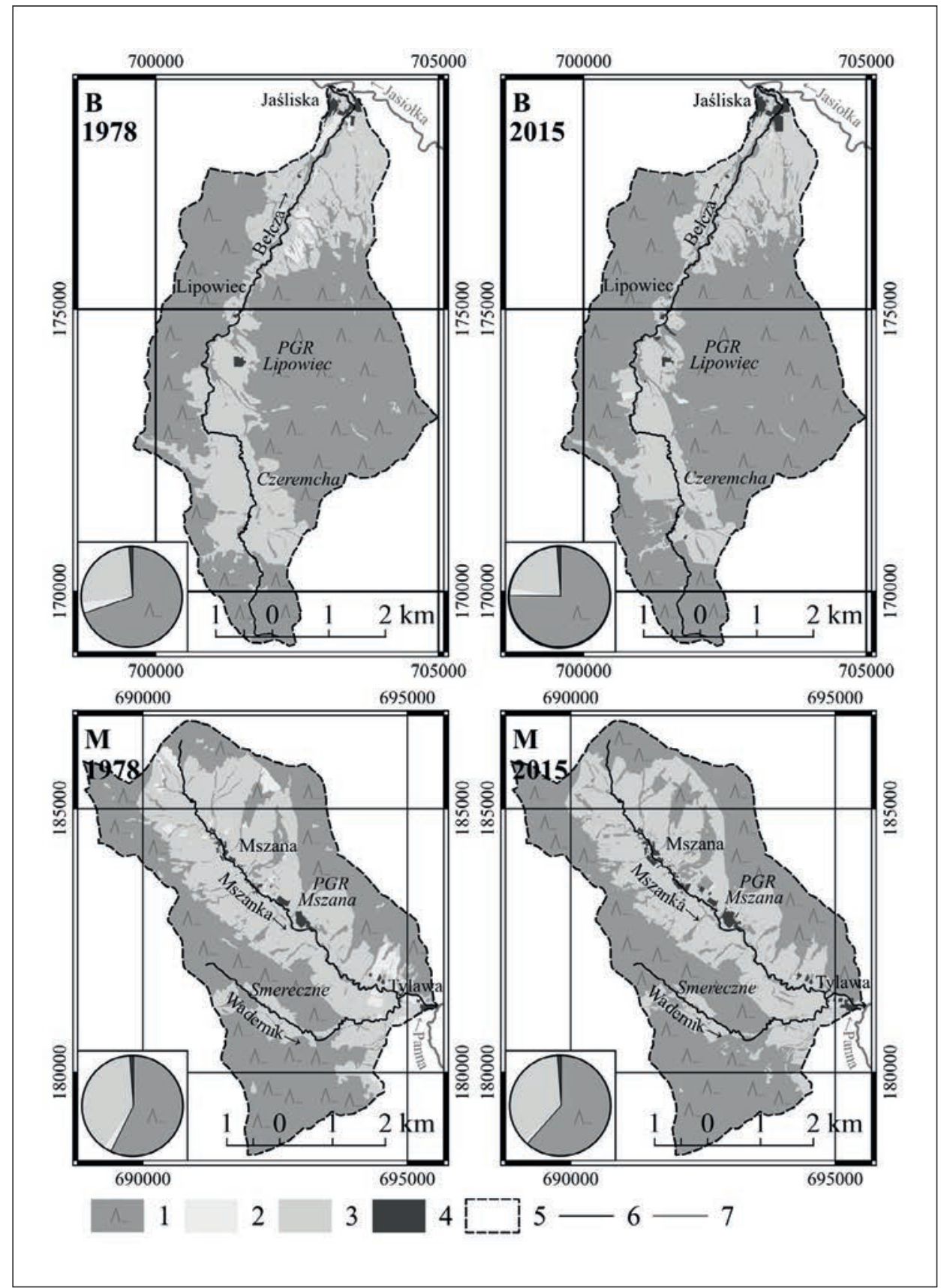

1 - lasy, 2 - pola uprawne, 3 - łąki i pastwiska, 4 - tereny zabudowane, 5 - granice zlewni, 6 - potoki w zlewniach, 7 - recypient. Nazwy nieistniejących jednostek osadniczych podpisano kursywą

Źródło: opracowanie własne 
Tabela 1. Zestawienie współczynników podobieństwa Kappa dla zmian pokrycia terenu w obu zbadanych zlewniach

\begin{tabular}{|l|c|c|}
\hline \multicolumn{1}{|c|}{ Kappa } & Zlewnia Bełczy & Zlewnia Mszanki \\
\hline Kappa histo & 0,94388 & 0,95502 \\
\hline Kappa location & 0,99567 & 0,98752 \\
\hline Kappa overall & 0,94074 & 0,94311 \\
\hline
\end{tabular}

Niewątpliwie największe zmiany zagospodarowania obu zlewni nastąpiły w połowie lat 40. XX w., kiedy na ich obszarze toczyły się działania wojenne i były dokonywane opisane wyżej przesiedlenia ludności. Działo się to przed okresem zbadanym w studium nad pokryciem terenu, które dotyczyło roku 1978 i 2015. Wykonanie podobnego badania $z$ uwzględnieniem np. materiałów przedwojennych lub tych po zakończeniu II wojny światowej jest wręcz niemożliwe, z uwagi na niewielką liczbę i znaczną fragmentaryczność materiałów fotogrametrycznych z tego okresu (Jucha, 2015).

W badanym okresie nastąpiły dwa ważne w skali krajowej wydarzenia, wpływające na zagospodarowanie: przemiany ustrojowo-gospodarcze w 1990 r. oraz przystąpienie Polski do Unii Europejskiej w 2004 r. W studium nad pokryciem terenu nie zaobserwowano jednak istotnych statystycznie zmian (rycina 2). Wykazane różnice na mapach, przygotowanych dla obu momentów czasowych, były bardzo niewielkie, a mapy wykazywały bardzo wysoki stopień podobieństwa wyrażony współczynnikiem Kappa (tab. 1). Wynik ten wyróżnia się na tle innych badań dotyczących zmian pokrycia terenu z przełomu XX i XXI w., w których zaobserwowano zdecydowanie większe zmiany w wydzieleniach o podobnej skali lub w opracowaniach regionalnych (Bański, 2003; Bucała, 2014; ; Dorocki i in., 2019; Kaim, 2009; Kozak, 2005; Kroczak i in., 2018; Trzepacz, 2011).

Państwowe Gospodarstwa Rolne przejęły po wysiedlonych Łemkach rozdrobnione działki rolne, na których częściowo występowała już sukcesja. Ustabilizowały one strukturę użytkowania, nawiązując do uprawy terenów łatwo dostępnych. Ich likwidacja po zmianie systemu politycznego w 1991 r. i aktywizacja przedsiębiorczości po wejściu do Unii Europejskiej, a szczególnie wprowadzenie dopłat do użytkowania w postaci łąk, pozwoliły na stabilizację struktury użytkowania terenu w ciągu badanych ostatnich 40 lat. Zaobserwowane zmiany były nieznaczne i nieistotne statystycznie.

Badanie odleglejszej przeszłości umożliwiają także mapy archiwalne, które pozwalają na poznanie zasięgu i zmian w użytkowaniu terenu (Dobrowolski, 1930). W ten sposób J. Lach (1993) przedstawił zmiany w strukturze użytkowania dla fragmentu wsi Lipowiec dotyczące roku 1851 i 1980 (rycina 3).

Badania prowadzone w tym terenie w latach 80 . XX w. nie wykazały zmian ekonomiczno-społecznych i w użytkowaniu terenu (Żychowski, 2000). Część gruntów była wcześniej wyłączona z użytkowania przez PGR i w tym okresie obserwowano w tych miejscach stopniowe zarastanie pól przez krzewy i drzewa.

A. Bucała-Hrabia (2018) zwraca uwagę na porzucenie gruntów uprawnych i sukcesję w trzech zlewniach w środkowej części polskich Karpat Zachodnich w latach 1975-2015. W okresie tym wystąpił największy wzrost gęstości zaludnienia i największy spadek liczby ludności, która utrzymywała się z rolnictwa. Natomiast w Beskidzie Niskim, po likwidacji PGR-ów w 1991, gdzie mieszkała relatywnie mała liczba osób, gęstość zaludnienia zaczęła stopniowo maleć. Zmniejszyło się także zatrudnienie w rolnictwie. Większość młodych 
Rycina 3. Zabudowa i podział na działki we wsi Lipowiec w 1851 r. (A) i pokrycie terenu w 1980 r. (B)
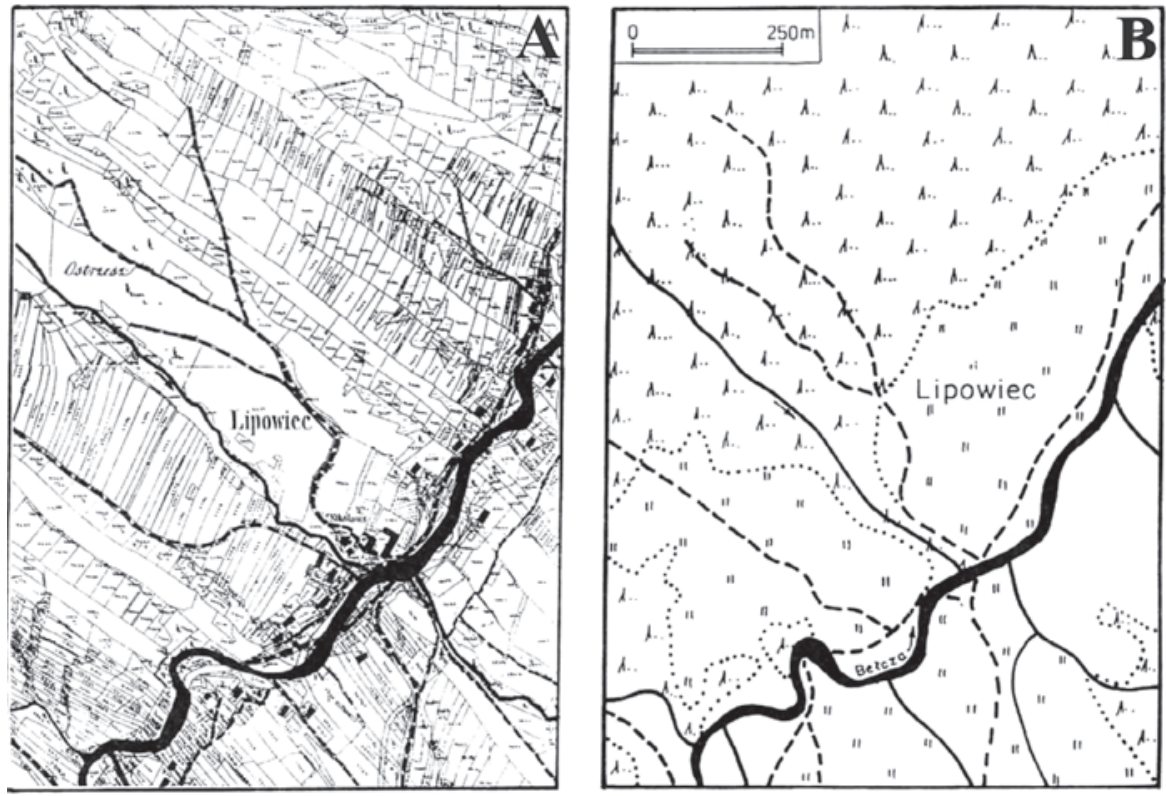

Źródło: Lach (1993)

mieszkańców bloków na terenie dawnego PGR-u w Mszanie zaczęło dojeżdżać do pracy w Dukli i Krośnie. Wspomniane procesy polityczno-ekonomiczno-społeczne wpłynęły inaczej na użytkowanie ziemi na tym obszarze niż w środkowych Karpatach ze względu na różnice własności gruntów (własność skomasowana w ramach działalności dawnego PGR-u). Na zachowanie użytkowania ziemi w formie wykaszanych łąk wpływ miały różne czynniki (tabela 2).

Tabela 2. Czynniki wpływające na zmiany zagospodarowania w zlewniach Bełczy i Mszanki w latach 1978-2019

\begin{tabular}{|c|c|l|l|}
\hline Lp. & Okres & \multicolumn{1}{|c|}{ Czynnik } & \multicolumn{1}{c|}{ Rezultat } \\
\hline 1. & Lata 80. XX w. & $\begin{array}{l}\text { Działalność PGR-ów w latach } \\
1978-1991\end{array}$ & $\begin{array}{l}\text { Upaństwowienie i komasacja ziemi } \\
\text { na terenach wysiedlonych. Stabilizacja } \\
\text { w użytkowaniu w sprzyjających uprawie } \\
\text { terenach }\end{array}$ \\
\hline 2. & Lata 90. XX w. & $\begin{array}{l}\text { Likwidacja PGR-ów 1991 r., } \\
\text { po zmianie systemu polityczne- } \\
\text { go. Stopniowe zmniejszanie się } \\
\text { liczby ludności }\end{array}$ & $\begin{array}{l}\text { Odłogowanie terenów, które stopniowo } \\
\text { zarastały w procesie sukcesji. Rozpoczęcie } \\
\text { prywatnej działalności agroturystycznej } \\
\text { oraz hodowli kóz, bydła mlecznego i koni }\end{array}$ \\
\hline 3. & XXI w. & $\begin{array}{l}\text { Wejście Polski do UE w 2004 r. } \\
\text { i ustanowienie dopłat do użyt- } \\
\text { kowania ziemi }\end{array}$ & $\begin{array}{l}\text { Wykup działek przez prywatnych inwe- } \\
\text { storów spoza terenu badań i rozpoczęcie } \\
\text { regularnego wykaszania oraz sporadycz- } \\
\text { nego karczowania. } \\
\text { Stabilizacja struktury użytkowania na } \\
\text { podobnym poziomie co w roku 1978 }\end{array}$ \\
\hline
\end{tabular}

Źródło: opracowanie własne na podstawie przeprowadzonych prac terenowych i wywiadu środowiskowego 


\section{Podsumowanie i wnioski}

Na terenie zlewni Bełczy i Mszanki w przeciągu ostatnich kilkudziesięciu lat nie wystąpiły istotne statystycznie zmiany w pokryciu i użytkowaniu terenu, lecz nastąpiła stabilizacja ich struktury. Działo się tak nawet pomimo stopniowego wyludniania się obu wydzieleń. Wpłynęły na to następujące czynniki:

- rozwój lokalnej przedsiębiorczości, po transformacji ustrojowej, w postaci działalności agroturystycznej oraz powstanie przedsiębiorstw produkcji rolniczej w tym nastawionej na produkcję ekologiczną;

- system dopłat do ekologicznego utrzymania łąk kośnych wprowadzony w ramach programów unijnych. Grunty zakupili często inwestorzy pochodzący spoza terenu badań.

W artykule przedstawiono przykład, jak czynniki polityczne i ekonomiczne wpłynęły na zmiany społeczne i w konsekwencji, dzięki przedsiębiorczości, doprowadziły do pożądanych efektów przyrodniczych w postaci ustabilizowania struktury użytkowania gruntów. Autorzy mają nadzieję, że przedstawiony materiał będzie także przydatny podczas dyskusji w procesie dydaktyki z zakresu przedsiębiorczości.

\section{Literatura}

References

Andrusikiewicz, J. (1968). Boje o Przełęcz Dukielską. Wierchy, 37, 157-169.

Bański, J. (2003. Współczesne i przyszłe zmiany w strukturze przestrzennej obszarów wiejskich - wybrane zagadnienia. Studia Obszarów Wiejskich, 41, 11-25.

Barwiński, M. (2009). Rozmieszczenie i liczebność Łemków w Polsce na podstawie wyników spisu powszechnego z 2002 roku - uwarunkowania i kontrowersje. W: S. Dudra, B. Halczak, I. Betko, M. Smigiel (red.), Łemkowie, Bojkowie, Rusini - historia, współczesność, kultura materialna i duchowa, t. II, Zielona Góra, 15-28.

Bucała, A. (2014). The impact of human activities on land use and land cover and environmental processes in the Gorce Mountains (West Polish Carpathians) in the past 50 years. Journal of Environmental Management, 138, 4-14. doi: 10.1016/j.jenvman.2014.01.036

Bucała-Hrabia, A. (2018). Land use changes and their catchment-scale environmental impact in the polish western carpathians during transition from centrally planned to free-market economics. Geographia Polonica, 91(2), 171-196.

Chata ekoturystyczna „Gutkowa Koliba”. (2019, 1 października). Pozyskano z: http://www.gutkowa-koliba.pl/

Chudyk, Al. (Hrabski, L.). (2016). Smereczne na Łemkowszczyźnie. Wspomnienia i relacje. KrosnoSmereczne: Oficyna Wydawnicza Ruthenic Art.

Czajkowski, J. (1999). Studia nad Łemkowszczyzną. Sanok: MBL.

Dobrowolski, K. (1930). Migracje wołoskie na ziemiach polskich. Pamiętnik V Powszechnego Zjazdu Historyków Polskich w Warszawie. Lwów: Polskie Wydawnictwo Historyczne, 135-152.

Dorocki, S., Kroczak, R., Bryndal, T. (2019). Zmiany pokrycia terenu w polskich Karpatach na przełomie XX i XXI w. a poziom rozwoju lokalnego. Przedsiębiorczość - Edukacja [Entrepreneurship Education], 15(1), 214-229. doi: 10.24917/20833296.151.16

Fastnacht, A. (1962). Osadnictwo ziemi sanockiej w latach 1340-1650. Prace Wrocławskiego Towarzystwa Naukowego. Seria A., 84, 56-61.

Figlus, T. (2016). Villae iuris valachici. Z problematyki rozwoju osadnictwa wołoskiego w Polsce na przykładzie ziemi sanockiej. Studia z Geografii Politycznej i Historycznej, 5, 11-37. 
Gospodarstwo Agroturystyczne „Ostoja w Lipowcu”. (2019, 1 października). Pozyskano z: http://www. lipowiec.pl/

Jawor, G. (2004). Osady prawa wołoskiego i ich mieszkańcy na Rusi Czerwonej w późnym średniowieczu, Lublin, 59-78.

Jucha, W. (2015). Możliwości i ograniczenia wykorzystania wojskowych zdjęć lotniczych z okresu II wojny światowej. Teledetekcja Środowiska, 53, 27-39.

Jucha, W. (2017). Struktura pokrycia terenu. W: P. Franczak (red.): Police: pasmo w cieniu Babiej Góry, Kraków: UJ, 437-446.

Kaim, D. (2009). Zmiany pokrycia terenu na pograniczu polsko-słowackim na przykładzie Małych Pienin. Przegląd Geograficzny, 81(1), 93-105.

Kroczak, R., Fidelus-Orzechowska, J., Bucała-Hrabia, A., Bryndal, T. (2018). Land use and land cover changes in small Carpathian catchments between the mid-19th and Elary 21st centuries and their record on the land surface. Journal of Mountain Science, 15(12): 2561-2578. doi: 10.1007/s11629029-5095-y

Kozak, J. (2005). Zmiany powierzchni lasów w Karpatach polskich na tle innych gór świata. Kraków. Wydawnictwo Uniwersytetu Jagiellońskiego.

Lach, J. (1993). Geomorfologiczne skutki zmiany granicy rolno-leśnej w dorzeczu Jasionki (Beskid Niski). Studia Ośrodka Dokumentacji Fizjograficznej PAN w Krakowie, 22, 181-193.

Meyfroidt, P., Lambin, E. F., (2011). Global forest transition: Prospects for an end to deforestation. Annual Review of Environment and Resources, 36, 343-371.

Moklak, J. (2013). Życie polityczne i religijne ludności łemkowskiej powiatu krośnieńskiego w latach 1918-1939 (z uwzględnieniem Pogórza Strzyżowskiego). W: S. Dubiel-Dmytryszyn (red.), Ruśkrośnieńska, szkice i studia na temat „wyspy” łemkowskiej. Węglówka: RuthenicArt, 39-58.

Maryański, A. (1963). Współczesne migracje ludności w południowej części pogranicza polsko-radzieckiego i ich wplyw na rozmieszczenie sił wytwórczych tego obszaru. Kraków: WSP.

Meyfroidt, P., Lambin E.F. (2011). Global forest transition: Prospects for an end to deforestation. Annual Review of Environment and Resources, 36, 343-371.

Rachwał, T., Kilar, W., Kawecki, Z., Wróbel, P. (2018). Edukacja w zakresie przedsiębiorczości w wychowaniu przedszkolnym, szkole podstawowej i szkołach średnich w świetle nowej podstawy programowej. Przedsiębiorczość - Edukacja [Entrepreneurship - Education], 14, 389-424.

Świętek, A. (2019). Miejsce podstaw przedsiębiorczości w zreformowanej polskiej szkole ponadpodstawowej i ich korelacje z innymi przedmiotami szkolnymi. Przedsiębiorczość - Edukacja, [Entrepreneurship - Education], 15(1), 34-46.

Trzepacz, P. (2011). Kierunki zmian zagospodarowania przestrzeni w Karpatach polskich na przełomie XX i XXI wieku. W: A. Ciołkosz, C. Guzik, M. Luc, P. Trzepacz (red.), Zmiany użytkowania ziemi w Karpatach polskich w okresie 1988-2006. Kraków: Instytut Geografii i Gospodarki Przestrzennej UJ, 113-120.

Żychowski, J. (2000). Przyczyny różnej transformacji opadów w odpływy w dwóch zlewniach Beskidu Niskiego. W: Z. Zioło (red.), Działalność człowieka i jego środowisko. Kraków: AP, 93-121.

Józef Żychowski, dr hab. prof. Uniwersytetu Pedagogicznego im. Komisji Edukacji Narodowej w Krakowie, Instytut Geografii, Katedra Ekorozwoju i Kształtowania Środowiska Geograficznego. Przewodniczący Oddziału Krakowskiego Polskiego Towarzystwa Geograficznego. Jego zainteresowania badawcze skupiają się przede wszystkim na wpływie użytkowania terenu na odpływy rzeczne w małych zlewniach oraz wpływie działalności człowieka na środowisko przyrodnicze. Jest on prekursorem badań w skali światowej nad wpływem nekropoli, w tym masowych grobów, na środowisko.

Józef Żychowski, professor at the Pedagogical University of Krakow, Institute of Geography, Department of Sustainable Development and Shaping of Geographic Environment. Chairman of the Krakow Chapter of the Polish Geographical Society. His research interests focus primarily on the 
impact of land use on river outflows in small catchment areas and the impact of human activity on the natural environment. He is a precursor of research on a global scale on the impact of necropolises, including mass graves, on the environment.

ORCID: https://orcid.org/0000-0003-3287-2615

\section{Adres/Address:}

Uniwersytet Pedagogiczny im. Komisji Edukacji Narodowej w Krakowie

Instytut Geografii

Katedra Ekorozwoju i Kształtowania Środowiska Geograficznego

ul. Podchorążych 2

30-084 Kraków, Polska

e-mail: jozef.zychowski@up.krakow.pl

Witold Jucha, dr, adiunkt w Uniwersytecie Pedagogicznym im. Komisji Edukacji Narodowej, Instytut Geografii, Katedra Geografii Fizycznej. Zainteresowania badawcze obejmują wykorzystanie Systemów Informacji Geograficznej w badaniach obszarów mokradłowych oraz ich zmian w świetle przemian pozostałych elementów środowiska.

Witold Jucha, $\mathrm{PhD}$, associate professor at the Pedagogical University of Krakow, Institute of Geography, Department of Physical Geography. Research interests include the use of Geographical Information Systems in studies on wetland areas and other elements of the environment.

ORCID: 0000-0002-2204-8721

\section{Adres/Address:}

Uniwersytet Pedagogiczny im. Komisji Edukacji Narodowej w Krakowie

Instytut Geografii

Katedra Geografii Fizycznej

ul. Podchorążych 2

30-084 Kraków, Polska

e-mail: witold.jucha@up.krakow.pl 